sciendo Порівняльна професійна педагогіка 9(1)/2019 Comparative Professional Pedagogy 9(1)/2019

DOI: $10.2478 /$ rpp-2019-0011

Postgraduate Student, OLENA MOSHENETS

Khmelnytskyi National University, Ukraine

Address: 11 Instytutska St., Khmelnytskyi, 29016, Ukraine

E-mail: elena.moshenets@gmail.com

\title{
GOALS, OBJECTIVES AND CONTENT OF PROFESSIONAL TRAINING FOR INTERNATIONAL COMMUNICATION SPECIALISTS IN THE UK
}

\section{ABSTRACT}

The article analyzes the goals, objectives and content of professional training for international communication specialists in the UK universities. It is found that professional training of international communication specialists aims to prepare a competent and competitive expert under the rapidly changing requirements of British society and the international labour market. They are expected to have the relevant basic professional knowledge, practical abilities and skills (leadership and managerial skills, high-level political and information culture, active social position, high responsibility, willingness and capacity for self-study). It is indicated that British degree programmes mainly seek to train specialists based on interdisciplinary and competency-based principles, focusing on learning outcomes. Upon the successful completion of the degree programme, the graduate must possess not only theoretical knowledge but also special and general abilities and skills, which are necessary for effective functioning in various contexts of public life. It is specified that in the context of competency-based approach, the UK higher education aims to develop future specialists' ability to independently acquire new knowledge throughout life, identify and realize their own intellectual and creative potential, strive for self-determination, social integration and self-development, which creates relevant conditions for acquiring highlevel professional competency in general and nurture professional culture in particular. It is concluded that British degree programmes in international communication consist of compulsory and optional modules. Each university is entitled to choose the number and content of compulsory and optional modules in accordance with the directions of scientific research of the department and scientific interests of students and lecturers.

Keywords: goals, objectives, content, professional training, international communication specialist, university, the UK.

\footnotetext{
АНОТАЦІЯ

У статті проаналізовано циілі, завдання та зміст професійної підготовки фахівців з міжнародної комунікації в університетах Великої Британії. Встановлено, що головною метою професійної підготовки фахівців з міжнародної комунікації в системі вищої освіти Великої Британії визначено підготовку конкурентоздатного фахівия в умовах швидкозмінних вимог британського суспільства та міжннародного ринку праці, який володіє відповідними фундаментальними фаховими знаннями, практичниими умінями та навичками, особистісними якостями (лідерські, управлінські, високий рівень політичної та інформаційної культури, активна громадська позиція, висока відповідальність, готовність та здатність до самоосвіти). Зазначено, щяо основний фокус освітніх програм стосується підготовки фахівців на міждисциплінарній основі
} 
8 sciendo Порівняльна професійна педагогіка 9(1)/2019 Comparative Professional Pedagogy 9(1)/2019

та компетенетнісно орієнтованих засадах, орієнуванні на результати навчання. 3 а умови успішного проходження програми професійної підготовки випускник повинен володіти не лите теоретичними знаннями, а й спеціальними $і$ загальними уміння й навичками, необхідними для ефективного функціонування у різноманітних контекстах суспільного життя. 3'ясовано, щуо у рамках компетентнісного підходу вища освіта Великої Британії націлена на формування здатності майбутнього фахівия до самостійного опанування новими знаннями впродовж життя, найбільш повного виявлення та реалізації власного інтелектуального і творчого потенціалу, самовизначення та сочіального інтегрування, розвитку індивідуальності, щуо створює умови для оволодіння високим рівнем професійної компетентності загалом, $і$ культурою професійної діяльності зокрема. Підсумовано, щзо британські освітні програми з міжнародної комунікаиії складаються з обов'язкових і вибіркових модулів. Вибір кількості $і$ змісту обов'язкових та вибіркових модулів покладається на університет відповідно до напрямів наукових досліджень факултету та наукових інтересів студентів та викладачів.

Ключові слова: ичілі, завдання, зміст, професійна підготовка, фахівець з міжнародної комунікаиї̈, університет, Велика Британія.

\section{INTRODUCTION}

In the UK, professional training of international communication specialists aims to prepare a competent and competitive expert under the rapidly changing requirements of British society and the international labour market. They are expected to have the relevant basic professional knowledge, practical abilities and skills (leadership and managerial skills, high-level political and information culture, active social position, high responsibility, willingness and capacity for self-study). British degree programmes mainly seek to train specialists based on interdisciplinary and competency-based principles, focusing on learning outcomes. Upon the successful completion of the degree programme, the graduate must possess not only theoretical knowledge but also special and general abilities and skills, which are necessary for effective functioning in various contexts of public life (Elbrekht, 2011).

\section{THE AIM OF THE STUDY}

The aim of the paper consists in analyzing the goals, objectives and content of professional training for international communication specialists in the UK universities.

\section{THEORETICAL FRAMEWORK AND RESEARCH METHODS}

The current research employed the range of methods, including theoretical and comparative analysis, induction and deduction, systematization, individualization and generalization.

Theoretical analysis of undergraduate degree programmes in international communication offered by the UK universities proves that the main goals of professional training for respective specialists are as follows:

1) to prepare creative and reflexive international communication specialists with profound knowledge about international studies on media and communication;

2) to provide students with intellectual knowledge, innovative abilities and skills, taking into account the requirements of employers;

3) to incorporate modern methods of teaching foreign languages and cultures into undergraduate degree programmes in international communication; and culture;

4) to provide students with the opportunity to obtain specialization in foreign language 
sciendo Порівняльна професійна педагогіка 9(1)/2019 Comparative Professional Pedagogy 9(1)/2019

5) to provide students with theoretical knowledge about the understanding of developing transnational media and communication systems in the context of globalization processes and the use of institutional and interpersonal communicative contexts which include intercultural interactions;

6) to teach students to analyze media texts and use communication research methods with a special emphasis on cross-cultural and media communications, as well as information and communication technologies in order to transmit information and justify one's own point of view;

7) to develop students' practical skills in the field of media industry and crosscultural communication skills and high-level communication skills, which is related to the graduate's ability to effectively communicate in oral and written form;

8) to develop students' critical and analytical skills (critical and analytical thinking) and ability to logically express one's ideas in various forms (written and oral) and formulate independent judgments;

9) to develop students' interpersonal skills, which aim to shape cross-cultural competency in establishing relationships with other people, in particular, constructive behaviour under the conditions of social diversity, statement of tolerance, curiosity, ingenuity, imagination;

10) to create relevant conditions for professional self-realization, self-development and successful career;

11) to provide internship and employment opportunities (Quality Assurance Agency, 2016).

Having systematized curriculum profiles of undergraduate degree programmes in international communication in the UK, the author of the research has singled out the following objectives:

1) to prepare students for professional activity, which involves acquiring professional knowledge, abilities and skills for effective work in the field;

2) to prepare students for research activities, which require that they should possess the knowledge, abilities and skills needed to perform professional research and innovation tasks in the field of international communication and the media industry, to implement interdisciplinary projects and independent research (media sector, culture and society, journalism, media, multimedia, public relations, radio, television and video);

3 ) to prepare students for professional activities, which involves acquiring professional knowledge, abilities and skills for effective work in the field;

4) to practically prepare students to effectively solve problems, take independent decisions, be creative when performing professional tasks (being communicators who understand media practices), integrate into various types of communications (social, interpersonal, interorganizational, cross-cultural, mass, media, formal, informal, verbal, nonverbal);

5) to cultivate students' social and democratic values, a sense of global citizenship, which involves encouraging them to address social issues, and engage in volunteer work;

6) to develop students' personal integrity, which involves creating the informational and educational space with the aim to meet the needs and interests of students.

The above-mentioned goals and objectives are realized by observing such relevant principles as accessibility, openness, humanization, scientificity, systemacity, continuity, flexibility, mobility; integration with science and production; communication theory with practice; individualization, activity; strength of knowledge acquisition, abilities and skills; 
sciendo Порівняльна професійна педагогіка 9(1)/2019 Comparative Professional Pedagogy 9(1)/2019

content variability, interdisciplinary integration, social dialogue, cultural reflection, orientation towards issues and communication, etc.

RESULTS

Having analyzed the content of undergraduate degree programmes in international communication, one can conclude that the process of developing professional competency in future international communication specialists involves acquiring a set of generic and subject-specific competencies (see Table 1).

Table 1

Competencies of future international communication specilaists

\begin{tabular}{|l|l|}
\hline \multicolumn{1}{|c|}{ Generic competencies } & \multicolumn{1}{c|}{ Subject-specific competencies } \\
\hline Communicative & Sociopolitical \\
\hline Creative & Research \\
\hline Self-study & Informational and analytical \\
\hline Managerial & Media \\
\hline Interdisciplinary & Conflictological \\
\hline Civil & Sociocultural \\
\hline Interpersonal & Cross-cultural \\
\hline
\end{tabular}

Systematized by the author

The results of developed professional competencies include the following: self-study skills, team-work skills, problem-solving skills, personal communication skills; practical, technical and creative abilities; understanding of professional media content and modern media culture; knowledge and critical judgments; skills in using theoretical discourses in the field of media texts and their cultural, economic and political contexts; understanding and use of verbal and visual linguistic means of media texts; creative, critical, research and analytical skills sufficient for designing research fragments on the chosen aspect of communication in modern media culture.

At Birmingham City University, specialists in interdisciplinary education, communication, media, cinema and cultural studies should demonstrate the following learning outcomes: knowledge of communication, media and culture, and their role at local, national, and international and global levels of economic, political and social organization; reasonable understanding of the historical formation of research objects, their contexts and interfaces; knowledge of relevant research practices, procedures and traditions; certain awareness of diverse approaches to understanding communication, media and culture in both historical and contemporary contexts; knowledge of numerous texts, genres, aesthetic forms and cultural practices; ability to conduct a detailed analysis of data and make comparisons; ability to use forms of critical analysis, arguments and discussions expressed through appropriate means of oral, written and other forms of communication; understanding of production processes and professional practices within the media, cultural and communicative industries; ability to engage in and develop creative processes in one or more forms of media or cultural production; knowledge of communicative situations and cross-cultural practices; ability to think critically and analytically and provide independent judgments; ability to work in different groups and under independent learning modes, demonstrate flexibility, creativity and critical self-reflection; ability to use their knowledge and understand communication, cultural and media processes as the basis for studying policy and ethical issues, etc. (Birmingham City University, 2018). 
The conducted analysis also indicates that considerable attention is paid to the process of developing communicative competency in future international communication specialists. Indeed, it is a prerequisite for effective implementation of the main professional duties, which include presenting and justifying the results of relevant research in the field of international communication through analytical reports, publication of articles, participation in roundtables, symposiums and conferences; comments on current events in the media; explanations of the provisions of political programmes designed by relevant structures, institutions and organizations, etc. Communicative competency is being developed throughout the degree programme by doing compulsory and optional courses which require participation in discussions, debates, presentations (oral communication) and essay preparation, analytical reports, scientific projects, articles (written communication). This, in turn, allows students to acquire abilities and skills in public speaking, argumentation, persuasion, presentation, performing various analytical work.

The process of developing information and analytical competency involves teaching students to use ICTs in various fields of communication, virtual educational environment with the aim to exchange materials and implement the principle of cooperation between lecturers and students; to obtain, store, exchange and process quantitative and qualitative data to prepare analytical articles, reports and presentations; encouraging students to participate in social networks and communities to exchange culture traits, establish social contacts and achieve professional goals. It is important that students should be able to conduct systemic analysis of facts and events and conceptualize the problem, that is to consider a certain situation in view of its influence on the realization of interests inherent in the subjects of political processes and international cooperation; to model the problem, that is to divide it into constituent components and establish causal relationships between them; to develop research programmes, that is to determine research goals, describe the organization and conduct of observations, identify the main factors affecting the situation, choose research methods; to develop alternative solutions to problems and evaluate them in terms of potential impacts; to formulate comprehensive analytical findings.

An important role in the process of training international communication specialists belongs to self-study skills. Thus, students should be able to engage in lifelong learning, apply time management skills, systematize their own knowledge and identify gaps, develop and implement programmes of independent study based on individual and social needs, acquire the necessary knowledge due to independent study of relevant materials, represent, justify and critically evaluate the result obtained during self-study.

Since the defining mechanisms for the implementation of international communications are communication, interaction and mutual influence, one should pay specific attention to interpersonal competency, which is the ability to coordinate issues related to social expectations and interactions for the successful performance of professional duties in the field of international relations, with emphasis on the development of competencies necessary for analytical and diplomatic work and effective communication at the international, regional and national levels. The process of developing interpersonal competency is based on the study of several foreign languages and profound knowledge of international relations, including the foundations of international law, international economics and business. Future specialists should be able to develop and implement effective communication strategies at the corporate, national and international levels, using modern ICTs and tools for information and analytical work. 
At the University of Leicester, Bachelors of Arts in International Communication and Culture should have intercultural / cross-cultural competency whose indicators include understanding of transnational structures and processes of media and communications; knowledge of theory and practice of intercultural communication, cultural artifacts and impact of different cultural contexts on cross-cultural communication; understanding of cross-cultural relations, communications and interactions in the context of a multicultural space; intercultural consciousness; ability to conduct dialogue with representatives of different cultures; knowledge of norms and rules of interpersonal interaction at the intersection of cultures; ability to cooperate, tolerate and openly respond to cultural features, solve cross-cultural conflicts, apply cross-cultural knowledge in practice; ability to perceive, compare and evaluate both similarities and differences of human behaviour, cultural traditions, beliefs, values in a cultural environment within one, two or more countries, as well as willingness to study culture and language of one's own and other peoples; a well-developed sense of tolerance and empathy in relation to other cultures and its representatives (University of Leicester, 2018).

Critical evaluation of evidence with the appropriate understanding of media content reflects media competency. The indicators of its development are as follows: ability to mediate a dialogue with other people; knowledge, skills and abilities necessary to analyze and synthesize spatial and temporal reality; ability to "read" media text and use mass media to meet information needs; self-expression by means of media technology; understanding of media functioning and the patterns of their existence; skills and ability to interpret media information, filter and critically understand it. These abilities ensure the individual's independence from the existing stereotypes and allow them to preserve critical autonomy and critical distance, that is to autonomize from the influence of the media and, therefore, preserve one's ability to be oneself.

Interdisciplinary competency of future international communication specialists involves shaping and developing the ability to apply knowledge, skills, modes of activity and attitudes within an interdisciplinary range of problems. This competency covers value orientations, knowledge, skills, modes of activity required and developed during the education process within an interdisciplinary field of specialist courses (media, television, public relations) and acquired personal experience. It plays an important role in professional activities of political scientists since they are able to consider any sociopolitical problem in the context of several scientific disciplines, establish connections and integrate disciplinary positions to form a coherent picture of a particular situation and discover some comprehensive solutions to it. At the University of Oxford Brooks, they state that one of the objectives of professional training is to deepen understanding of various theoretical, methodological and analytical prospects which comprise the landscape of modern political science and teach future specialists to apply these prospects in different contexts and at different levels of analysis (Oxford Brookes University, 2018). At the University of Bristol, they indicate that it is aimed at teaching political science in combination with other related fields of knowledge since it will provide students with thorough understanding of political features of the modern world and will allow them to use a variety of prospects and specificity of political science as a field of knowledge. The need for this competency is determined by general tendencies towards the complication and diversification of the political life of society in the context of active globalization processes (University of Bristol, 2018). 
Sociopolitical competency implies the ability to create image and brand of the state or organization in the national and international arena; skills in implementing activities in the field of cultural and public diplomacy; ability to organize press services in state and commercial institutions; ability to detect and use methods of manipulating mass consciousness and misinformation in the media and on the Internet; strategic skills in attack and defence under conditions of information confrontation (war); ability to analyze and predict national and international events and behaviour of the subjects of international relations; readiness to conduct analytical research on relevant sociopolitical issues; ability to plan and conduct PR campaigns at the national and international levels; ability to prepare information and analytical materials for national and international TV and radio companies, etc. The graduate should demonstrate tolerance and understanding of differing viewpoints, trace and interpret the dynamics of communicative exchanges during communication, present themselves, ensure cooperation, coordination and social influence which will allow them to establish constructive relationships with the subjects of political interaction differing in their social roles, motivational factors, expectations and also direct them to accept certain behaviours, beliefs, values and attitudes.

The Coventry University's Department of Arts and Humanities offers professional training in International Communication BA (Hons)). The degree programme allows students to familiarize themselves with the theory of international communication, global platforms, journalism, media content, strategies and communication tactics, as well as learn to apply analytical and informational skills and skills in developing communication processes. As for language learning, students can improve their skills and abilities of oral and written speech, analytical thinking and deepen understanding of other cultures. The ability to be fluent in a particular language involves acquiring a wide range of cognitive, social and interactive knowledge and skills. Therefore, the intellectual toolset needed for language proficiency must be based on certain scientific principles. Taking into account interdisciplinarity, British educators consider it necessary to incorporate the principles of formal logic, psychology, philosophy, sociology, anthropology and neurology into degree programmes. Understanding the economy is becoming increasingly necessary for understanding the processes of law-making, doing business, economic transformations which take place in the modern world (Coventry University, 2018).

At Birkbeck University, they offer a degree programme in intercultural communication, too. As part of the programme, students study intercultural communication, as well as familiarize themselves with communication in different cultural contexts, namely French, German, Italian, Japanese or Spanish. Choosing from a range of modules covering literature, cinema, history, visual culture and philosophy, students learn about different communication practices in different international contexts. The programme includes 360 credits usually allocated to languages/cultures and linguistics and communication. During the first year of study, students master two main modules (approaches to language learning) and two modules related to culture (culture of understanding: language and text) or languages (French, German, Italian, Japanese, Spanish). During the second year of study, students master two compulsory modules (language and intercultural communication in the business context), while the other 90 credits consist of modules in terms of culture, language or linguistics. During the third year of study, students master two modules (professional communication skills and a portfolio of intercultural communication), while the other 60 credits consist of modules related to culture, language or linguistics. Learning 
sciendo Порівняльна професійна педагогіка 9(1)/2019 Comparative Professional Pedagogy 9(1)/2019

languages and cultures, students develop their thinking, ability to critically evaluate and logically justify judgments and learn to apply their knowledge, skills and abilities to address moral and ethical issues. In addition, students work on a project on linguistics / psycholinguistics to develop their research culture (Birkbeck, University of London, 2018).

\section{CONCLUSIONS}

The conducted analysis on the content of British degree programmes in international communication shows that international communication is actively combined with economics, international business, media industry, linguistics, history, sociology, foreign languages, international relations. The study on the structure of degree programmes proves that they consist of compulsory and optional modules. Each university is entitled to choose the number and content of compulsory and optional modules in accordance with the directions of scientific research of the department and scientific interests of students and lecturers. Normally, an invariant part of the content of undergraduate degree programmes in international communication is equal to $50 \%$ of the total study time, while the remaining $50 \%$ are modules at the student's free choice.

Prospects of further studies should be directed at studying the development of research competency in future international communication specialists.

\section{REFERENCES}

1. Asal, V., \& Kratoville, J. (2013). Constructing international relations simulations: examining the pedagogy of IR simulations through a constructivist learning theory lens. Journal of Political Science Education, 9 (2), 132-143.

2. Birkbeck, University of London. (2018). Intercultural Communication (BA). Retrieved from http://www.bbk.ac.uk/study/2019/undergraduate/programmes/UUBAIN CM_Cl.

3. Birmingham City University. (2018). Courses. Retrieved from https://www.bcu.ac.uk/ courses.

4. Coventry University. (2018). International Communication BA. Retrieved from https://www.coventry.ac.uk/ug/p502/.

5. Elbrekht, O. M. (2011). Standartyzatsiia vyshchoi osvity yak zasib udoskonalennia profesiinoi pidhotovky fakhivtsiv. Pedahohika, psykholohiia ta medyko-biolohichni problemy fizychnoho vykhovannia i sportu, 9, 38-42.

6. Ganobcsik-Williams, L. (2006). Teaching academic writing in UK higher education: theories, practices and models. London: Palgrave.

7. Griffin, G., Medhurst, P., \& Green, T. (2006). Interdisciplinarity in interdisciplinary research programmes in the UK. Hull: University of Hull.

8. Healey, M., Jenkins, A., \& Lea, J. (2014). Developing research-based curricula in college-based higher education. Retrieved from https://www.heacademy.ac.uk/system/ files/resources/developing_research-based_curricula_in_cbhe_14.pdf.

9. Oxford Brookes University. (2018). BA Politics. Retrieved from https://www. brookes.ac.uk/courses/undergraduate/politics/.

10. Tretko, V. (2013). Mizhdystsyplinarnyi pidkhid u pidhotovtsi maibutnikh mahistriv mizhnarodnykh vidnosyn. Osvita doroslykh: teoriia, dosvid, perspektyvy, 6, 94-102. 
11. Quality Assurance Agency. (2016). Subject Benchmark Statement for Communication, Media, Film and Cultural Studies. Retrieved from https://www.qaa.ac.uk/ docs/qaa/subject-benchmark-statements/sbs-communication-media-film-and-cultural-studies-16. pdf?sfvrsn=4fe $1 \mathrm{f} 781$ _ 12 .

12. University of Bristol. (2018). BA Politics. Retrieved from http://www.bristol.ac.uk/ study/undergraduate/2019/politics-international-relations/ba-politics-italian/.

13. University of Leichester. (2018). Courses. Retrieved from https://le.ac.uk/ courses?level $=$ Undergraduate $+2019 \& \mathrm{q}=$. 